\title{
Trusting/distrusting auditors' opinion
}

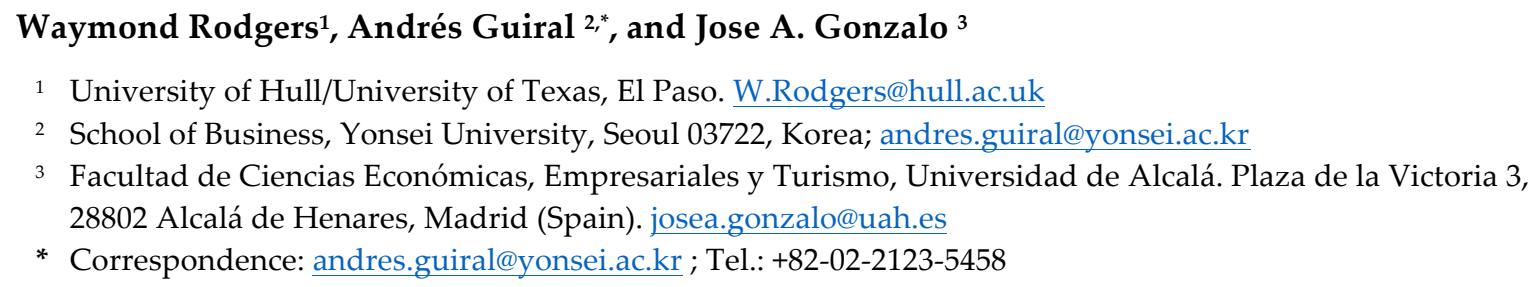

Abstract: Trust relations are essential for effective interchanges in the financial markets. Investors (trustors), as well as other market participants, can only trust financial markets if they trust their auditors (trustees). Especially, auditors' assessment on the client's financial condition and its ability to continue as a going concern is paramount to improving social capital and maintaining sustainable financial markets. Research shows that a going concern opinion may have immediate consequences for both the auditing profession and financial statement users. We utilize the Throughput Model to illustrate how different trust positions are aligned with a particular auditor's decision-making pathway to enhance trust, distrust or no trust from the point of view of investors' and creditors'.

Keywords: trust; social capital; audit report; sustainable financial markets

\section{Introduction}

The main question posed in this paper inquires: Are financial information users' decisions influenced by their trust in auditors' opinions? Given the apparent relationship between auditors and stakeholders (such as creditors, investors, unions, regulators, interest groups), it seems paramount to understand in what manner trust can nurture or erode social capital when parties interact [1]. According to Putnam [2] (p. 167), social capital can be defined as "features of social organization, such as trust, norms, and networks, that can improve the efficiency of society by facilitating coordinated action." Szczepankiewicz [3] (p. 319) argue that the value of social capital in organizations is rooted in mutual social relations and trust units, which thanks to it can achieve more social and economic benefits. Coleman [4] (p. 98) articulated that, "like other forms of capital and human capital, social capital is not completely fungible but may be specific to certain activities. A given form of social capital that is valuable in facilitating certain actions may be useless or even harmful to others."

The primary goal of the accounting profession is to enhance social capital by honoring public trust. Specifically, auditors contribute to society by assessing the truth and fair view of their clients' financial statements [5-7]. In honoring public trust, auditors should act as the guardians of third parties' interests rather than evaluate the consequences of their opinions in their relationship with their clients.

When suspicion arises that auditors are not providing reliable and relevant information to third parties, distrust may emerge [8]. Furthermore, if society believes that the auditor function is of little or no value, then trust can be eroded [9-11]. In this paper, we share the view that trusting and distrusting cannot be understood as the opposite ends of a continuum [8-12]. Accordingly, we argue that the very complexity of the trustworthiness in auditors' function relies on simultaneous high levels of trust-distrust relations [8].

Although some previous research investigates the association between trust and reputation of different parties [13-15], research on the link between auditors and society is lacking [16, 17]. In this paper, we focus on auditors' going concern opinions, probably the hardest and more controversial 
task for this profession [18]. A going concern opinion is a powerful warning signal that might negatively influence investors and other stakeholders in terms of credit re-allocation. However, previous literature shows that auditors face trust dilemmas and potential economic and non-economic incentives influencing their decisions, such as the possibility of being fired by their own clients [7].

To illustrate this phenomenon, we utilize the Throughput Model [19-20] to demonstrate how different trust positions are aligned with a particular decision-making pathway to enhance trust, distrust or no trust. Particularly, we discuss six dominant trust positions taken from Kramer [21]: a rational choice, rule-based trust, category-based trust, third parties as conduits of trust, role-based trust, and history-based trust/dispositional-based trust, and apply them to the auditors' going concern opinion. Because of the essential role played by auditors, we argue that a better understanding of the aforementioned trust/distrust positions will contribute to improving social capital and maintaining sustainable financial markets. This is important, since financial sustainability is the foundation upon which both social and environmental sustainability rest [22].

The next section deals with trust definitions, followed by a section devoted to explaining the institutional trust nature between auditors and primary stakeholders, such as stockbrokers, shareholders, financial institutions, employees, and society. This section is followed by how the decision-making model, The Throughput Model, is related to the dominant determinants of six trust positions. Then, the case of the author's opinion about the going concern evaluation and the six trust decision pathways are discussed. Lastly, we provide our conclusions and implications.

\section{Trust, Trustworthiness and the Going Concern Opinion}

\subsection{Social Capital and Trust}

Trust is viewed in this paper as (1) a body of beliefs or expectations, and (2) a tendency to behave with those beliefs accordingly [23]. These beliefs or expectations have grown up due to often long-lived relationships, intense in nature when there may be a great depth to the relationships between the parties, or where there are frequent interactions between them; the parties may also be reciprocally interdependent, and bounded whether by law or contract, such that the parties have incentives to maintain their relationship [24-25].

Trust affects auditors' positions within networks by influencing investment and credit decisions. However, distrust can also provoke negative effects, e.g., auditors' clients not receiving financing in a timely manner, and hence going out of business [26-27]. Gambetta [28] also emphasizes that uncertainty can lead to distrust and less cooperation. Others [21] have suggested that individuals' reactions, in term of defensiveness, may depend on the level of trustworthiness in a given relationship. That is, stakeholders, relying on auditors' viewpoints, may experience difficulties when interpreting organizational information and values and, therefore, will find these less accurate, whereby an increased distortion of messages may result. Therefore, understanding trust and distrust relationships are required for effective problem-solving in organized capital markets worldwide [29]. When financial statement users rely on auditors' opinions, they recognize their common interests and cooperative relations may take place [30].

Trustworthiness can be viewed as the underlying base that promotes an efficient solution to problems of coordinating expectations and interactions between individual actors [20, 31-33]. Figure 1 summarizes the connection between trust/distrust/no trust scenarios and social capital. In the trusting/distrusting situations, we differentiate three types of trustworthiness: incentive-based, normatively based, or psychologically based. Incentive-based trustworthiness refers to the incentives of the trusted person in order to act in accordance with that trust. Incentive-based trust is rooted in a precise alignment with the motivations and desires of the other party, i.e., encapsulated interest, allowing one to serves as an "agent" for the other and as a substitute for trades and other interpersonal relations [34]. The second type of trustworthiness relies on the use of standards, rules or abstract universal principles rooted in moral commitment autonomy under the social capital framework. The third type of trustworthiness relates to reasons of character or psychological 
disposition towards problem-solving and decision making. Finally, there is also possible a "no trust" scenario, where trustworthiness is null and may provoke undesirable effects, such as negative market responses and absence of reliable and relevant information.

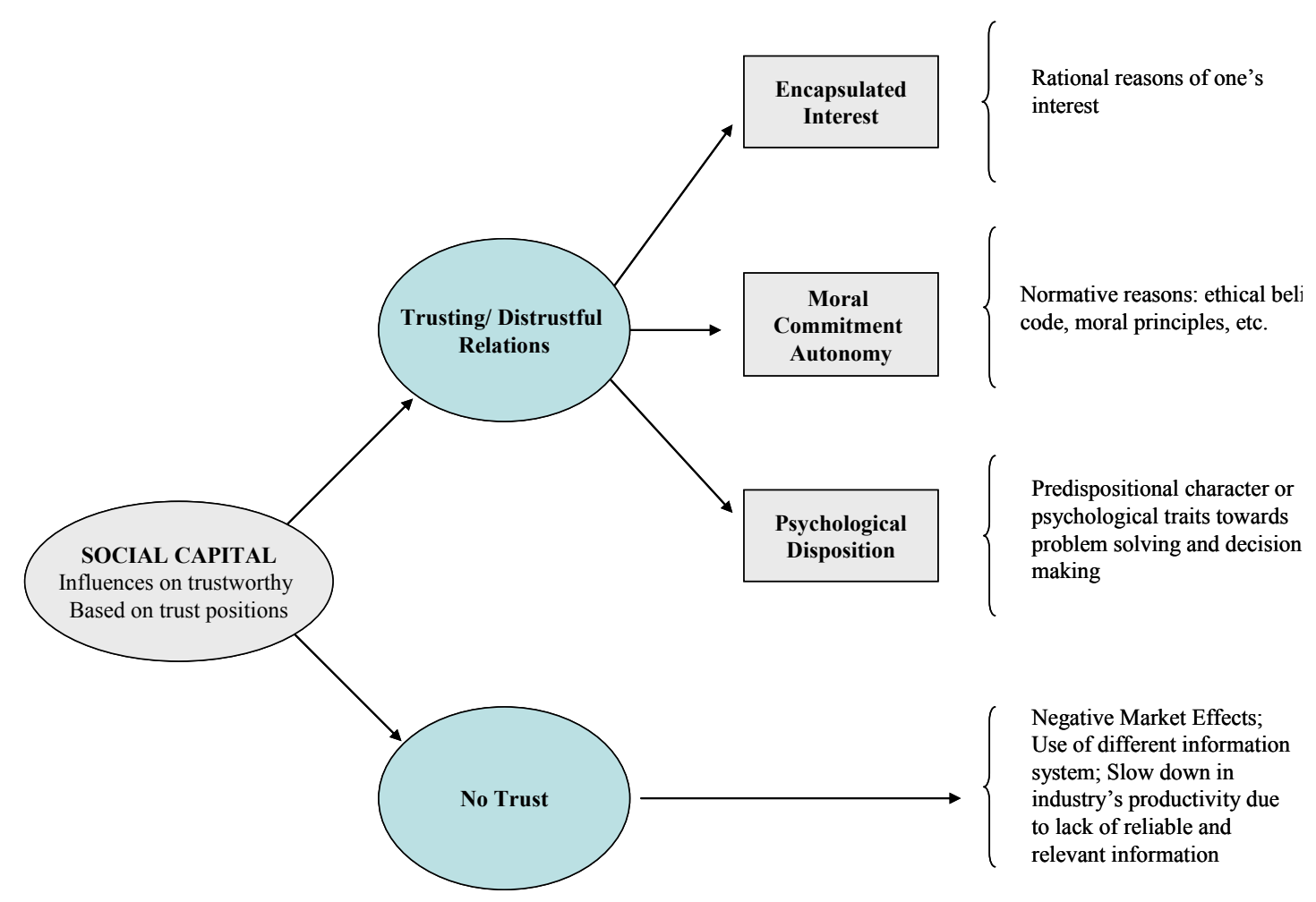

Figure 1. Trust/Distrust/No Trust scenarios \& Social capital.

\subsection{Auditors' Going Concern Opinions}

As stated by Duska, "society has carved out a vital role for the independent auditor that is absolutely essential for the effective functioning of the economic system" [35] (p.21). In this way, the auditor's opinion on their clients' ability to continue in existence is an act to establish trust with stockbrokers, creditors, investors, employees, and society. That is, financial statement users need to know the possibility that an organization may go bankrupt and the auditor is expected to deliver such critical information $[6,36]$.

The irony of this relationship is that an organization (client) hires the auditor to report to third parties whether the client is truthfully revealing the outcomes and status of its operations [24] ( $p$. 39). Furthermore, auditors' going concern opinions are often associated with Type Error I (i.e., firms that receiving a going-concern opinion survive in the subsequent year) and Type Error II (i.e., firms that do not receive a going-concern opinion but subsequently going bankrupt) [37]. While auditors' opinions should be rooted in normative reasons, previous research indicates that their decisions are subject to several economic incentives and psychological biases [6-7]. Uncertainty appears to be an unavoidable feature of trust. However, if individuals are uncertain about the auditor's opinion, they might as well refrain from trusting, and seek other less informational sources. This would result in an undesirable effect since auditors are supposed to be the guardian of public trust [35].

In the next section, the Throughput Model and its relation with dominant determinants of six trust positions are discussed. We then illustrate the six trust pathways with the case of the auditors' going concern opinion, before we present the conclusions and implications of this paper.

\section{The Throughput Conceptual Model}

The Throughput Model technique has been widely used to explore different financial and social issues such as lending [38-39], CEO's ethical reasoning [40-42], auditors' decisions with 
environmental risk information [6-7, 43-44], information processing [45] and sexual harassment [46].

The Throughput Model decomposed the ethical decision- making process into four main stages, namely perception (P), information (I), judgment $(\mathbf{J})$ and decision outcome (D) to isolate six predominant ethical pathways (see Figure 2). As shown in Figure 2, information is likely to affect the way an individual perceives a circumstance. But perception is also likely to influence how individuals rely on the information to be employed in the decision-making process. Therefore, under the Throughput Model lens, both perception and information are mutually dependent (see the double-ended arrow in Figure 2).

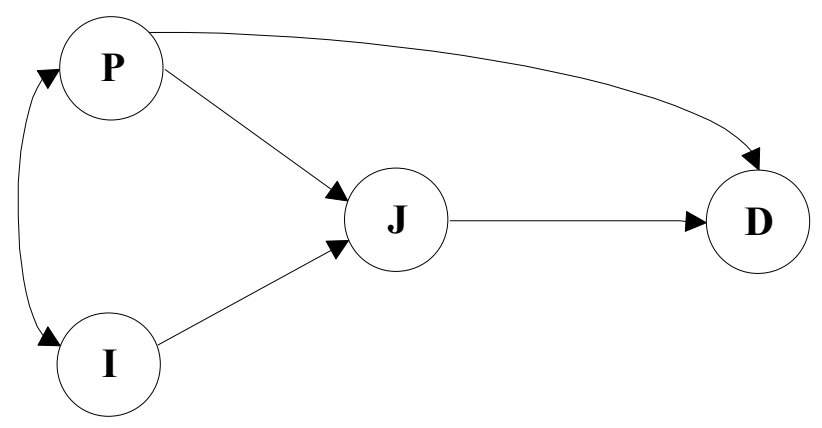

Figure 2. Throughput Model. Source: Rodgers [16, 45].

The first processing stage (perception in Figure 2) involves the framing of an organization's problem or a circumstance $(\mathbf{P})$. For the auditing case, framing implies the risk being perceived by the auditor in the organization's financial statements. An example of this framing is the auditor's assessment of the client's internal controls. When internal controls are robust, audit risk will be perceived as low compared to a client with a weak internal control system.

An organization's information (I) as portrayed by auditors' viewpoint can influence trust relations. Wicks et al. [47] argued that trust "lowers agency and transaction costs..., promotes smooth and efficient market exchanges..., and improves organizations' ability to adapt to complexity and change" ( $\mathrm{p}$. 99). For example, John Morrissey, deputy chief accountant of the Securities and Exchange Commission stated that the enhanced rules of the Ethics Committee of the International Federation of Accountants "... are based on the need to maintain investors' confidence and trust in the reported numbers, through the services of an auditor that will be perceived as objective and unbiased." [48] (p. 2)

The judgment stage (J) is critical in the auditor decision- making process. Both financial and non-financial information are compiled at the subconscious level to develop alternative solutions or courses of action by using compensatory or non-compensatory weighting methodologies [38, 49].

The trust decision (D) is rooted in positive confidence in the trustworthiness one attributes to another party. Currall and Epstein [50] (p. 194) stated: "Therefore, trust arises from judgments we make about the likelihood that another party will behave in a trustworthy manner as well as assessments we make about the possible costs we will suffer if the other party turns out to be untrustworthy." In this paper, we explore investors and stakeholders decision to trust or distrust auditors' opinions.

\section{Six Dominant Trust Pathways}

Once we have decomposed the ethical decision- making process into its four main stages, we use the Throughput Model to conceptualize the dominant determinants of the above six dominant decision-making pathways: (1) rational choice-based trust, (2) rule-based trust, (3) category-based trust, (4) third parties as conduits of trust, (5) role-based trust, and (6) history-based trust/dispositional-based trust [40]. Although other alternative pathways are also possible, they do not do so as significantly as the dominant pathways. These dominant positions enhance or weaken social capital based on the situation or contextual framework (see Table 1 and Figure 2). Furthermore, these pathways can be divided into two broad categories: primary and secondary. (1) Rational choice, (2) rule-based trust, (3) category-based trust are three primary trust pathways since 
they either focus on perception (P) or evidence (I). Whereas, (4) third parties as conduits of trust, (5) role-based trust, and (6) history-based trust/dispositional-based trust are secondary since they include both " $\mathrm{P}$ " and "I" [38].

\begin{tabular}{|lllll|}
\hline$\#$ & $\underline{\text { Trust Position }}$ & $\underline{\text { Pathway }}$ & $\underline{\text { Type }}$ & $\underline{\text { Social Capital }}$ \\
(1) & Trust as a rational choice & $\mathrm{P} \rightarrow \mathrm{D}$ & primary & Encapsulated interest \\
(2) & Rule-based trust & $\mathrm{P} \rightarrow \mathrm{J} \rightarrow \mathrm{D}$ & primary & Moral Commitment Autonomy \\
(3) & Category-based trust & $\mathrm{I} \rightarrow \mathrm{J} \rightarrow \mathrm{D}$ & primary & Psychological Disposition \\
(4) & Third parties as conduits of trust & $\mathrm{I} \rightarrow \mathrm{P} \rightarrow \mathrm{D}$ & secondary & Psychological Disposition/Encapsulated interest \\
(5) & Role-based trust & $\mathrm{P} \rightarrow \mathrm{I} \rightarrow \mathrm{J} \rightarrow \mathrm{D}$ & secondary & Psychological Disposition \\
(6) & History-based/dispositional trust & $\mathrm{I} \rightarrow \mathrm{P} \rightarrow \mathrm{J} \rightarrow \mathrm{D}$ & secondary & Psychological Disposition/Moral Commitment Autonomy \\
& & & & \\
\hline
\end{tabular}

Table 1. Trust Positions connected to Social Capital.

$\mathbf{P} \rightarrow \mathbf{D}$ depicts the most direct pathway to a goal or decision choice from a perceptual point of view. That is individuals frame a problem based upon their experiences, training and education and make a decision choice. Moreover, perception and information are coherent, which is to say that incoming information is constantly updating perception similar to a Bayesian statistical approach. Trust as a rational choice indicates that people are typically stirred to behave in their self-interest [51]. In addition, trust decisions are expected to be comparable to other types of risky choice in that people are recognized to be motivated to make rational and efficient choices, thereby improving social capital between auditors and society. That is, in accordance with traditional economic models, individuals are assumed to take action to exploit expected gains or reduce expected losses from their dealings. This viewpoint comprises two primary components [52]. First, knowledge is contemplated, which drives a person to trust another person, place or thing. Second, it associates with the trusted person's incentives to honor that trust. This particular kind of trust is predicated on a broad grasp of the other individual's wants, needs, and desires; i.e., it is rooted in the encapsulated interest concept under the social capital framework. Consequently, this particular kind of trust permits one to act on behalf of (i.e., "agent") the other and replace the other individual in interpersonal dealings [34]. Hardin [52, p. 189] stated: "You can more confidently trust me if you know that my interest will induce me to live up to your expectations. Your trust then encapsulates my interests."

Investors and stakeholders see auditors as an expert "agent" who contributes to minimize expected losses or maximize expected gains in their transactions. If they are convinced that information focuses auditors on maximizing third parties' interests, they are more likely to trust (distrust) them. This leads to the first proposition:

$\mathrm{P}_{1}$ : Auditors' opinions on an organization's information are trustworthy (untrustworthy) to the extent that they (do not) protect/maximize third parties' interests.

(2) $\mathbf{P} \rightarrow \mathbf{J} \rightarrow \mathbf{D}$ illustrates rule-based trust and focuses on the use of standards or laws which are rooted in moral commitment autonomy under the social capital framework. In other words, rules hinge on the arrangement of the decision choice together with the relational behavior of the driver of the action. The underlying and interpersonal mechanisms of rules are to be expected to prompt 
perceived trust [53] (p. 88) and increase or decrease social capital. Hummels and Roosendaal [54] asserted that "way to deal with complexity is to draw up an extensive contract that specifies the rights and obligations of the contract partners and to decide on the penalties when one of the parties fails to meet its obligations." $\mathbf{P} \rightarrow \mathbf{J} \rightarrow \mathbf{D}$ assumes that direct evidence influence from $\mathbf{I}$ is downplayed and a trust decision is formed through judgment. Evidence is just ignored due to lack of reliability and an individual forms a perception with small or no weights on information. Then, he or she assesses alternative scenarios based on perception to arrive at a trust decision.

Currall and Epstein articulated that [50] (p. 196) "Because it involves such personal consequences, trust is a largely solitary decision. Under certain conditions, our decision to trust also may be influenced by what family or friends do or urge us to do. Indeed, it is common for us to be swayed to trust someone by what others tell us about him or her." Kant's Categorical Imperative states [55] (p. 1) "if it was right for one person to take a given action then it must be right for all others to be encouraged to take that same action." Currall and Epstein also stated that "Furthermore, although trust is an evidentiary decision, we may use family members' or friends' experience as a proxy for our own. And, because trust decisions are often made in the context of incomplete information, we may seek out the advice of others as a supplement to our own information." [51] (p. 196). Individuals maintain a set of values that are either implicitly or explicitly understood. Besides, philosophers, religious and non-profit organizations have emphasized and promoted ideal sets of ethical principle or rules [40]. Illustrations of accepted moral values or rules at the implementation stage comprise bylaws, spiritual dogmas, trust codes for specialized and licensed groups, such as auditors, and a code of conduct at the organizational level. This leads to the second proposition:

$\mathrm{P}_{2}$ Society's perception that auditors' follow a higher (lower) level of standards (rules) than other market participants will result in a higher (lower) reliance on an organization's information.

(3) $\mathbf{I} \rightarrow \mathbf{J} \rightarrow \mathbf{D}$ depicts that category-based trust relies on commitment and collaboration rooted in group belongingness. Category-based trust may be extended broadly within psychological disposition under the social capital framework and may be reinforced by ceremonial and figurative actions [56] that underline cultural similarity [57]. However, collaboration can exist without trust [58]. Trust can also be viewed as a means of promoting cooperation when other methods may not work or be as efficient. People are more willing to assign positive characteristics relating to honesty, cooperativeness, and trust to individuals within a particular group [59]. On the other hand, if common characteristics are absent, distrust can arise when dealing with an ethical issue (e.g., the prisoners' dilemma game) [52]. A game such as "prisoner dilemma" can be implemented to discover how cooperation between unrelated parties can develop by normal choice. For example, in this type of game, each participant can either "cooperate" (invest in a common good) or "not cooperate" (exploit the other's investment). Institutional form may obtain acceptability predicated upon perceptual framing pertaining to the trust on behalf of authoritative powers. Powell and Dimaggio [60] argued that an institute is a respected source to the degree that its structure and procedures follow the decrees of established laws and beliefs. This leads to the third proposition:

$\mathrm{P}_{3}$ More (fewer) market transactions occur when society believes that a trustworthy (distrustworthy) auditing professional was responsible for reporting habits of organizations.

(4) $\mathbf{I} \rightarrow \mathbf{P} \rightarrow \mathbf{D}$ emphasizes the third parties as conduits of trust and supposes that individuals use themselves or people within close proximity to them as their foundation for delineating ethical standards in lawless settings thereby impacting on social capital. Third-party material assists to underpin prevailing relationships, enforcing one's perception to be assured of his trust (or distrust) 
in a person, place or thing. Furthermore, the study conducted by Labianca et al. [61] demonstrated that third parties might be pulled into damaging interpersonal exchanges. Hence, trust rest on the undeviating link amid two entities as opposed to their indirect links through third parties and the circumstances that the strong indirect links, which augment trust overturn their effect to generate distrust. The certainty may also be an illusion of whether or not the individual or the institution is trustworthy or not. Likewise, Blau [62] (p. 112-113) argued that trust progresses since social exchange involves unspecified obligations for which no binding contract can be written. Henceforth, trust is obligated to a swap deprived of a person knowing how the other individual will respond. This leads to the fourth proposition:

$\mathrm{P}_{4} \mathrm{Bad}$ (good) publicity of an organization will influence auditors to issue a negative (positive) opinion on an organization's financial reporting.

(5) $\mathbf{P} \rightarrow \mathbf{I} \rightarrow \mathbf{J} \rightarrow \mathbf{D}$ accentuates that role-based trust is knotted to recognized societal configurations, contingent on a person or organizational particular social capital features. This particular pathway suggests that a person's perceptual problem framing will inspire the assembly and information kind to be exercised in analysis (i.e., judgment). In other words, a person is encouraged to act aptly (i.e., perception) that impacts upon the information compendium implemented to be evaluated (i.e., judgment) in advance of a trust decision choice. This viewpoint put forward that an ethically compelled person with suitable inspirations is more likely to understand what task should be accomplished than an ethically deficient person would do. Beauchamp and Bowie [63] (p. 39) advocated: "A person who simply follows rules of obligation and who otherwise exhibits no special moral character may not be trustworthy." Simon [64] (p. 125) proceeded that the inclination to undertake an expert's decisions can happen through respect to the authorities' administrative part and can be made "independently of judgments of the correctness or acceptability of the premise (of their decisions)." Likewise, Tyler and Degoey [65] maintained that people's assessments of organizational authority trust formed their readiness to receive the authorities' actions as well as prompting a state of mind of commitment to follow institutional rules and laws. Besides, Fisher et al. [66] acclaimed that people are bound together by professional positions within the social order. The special trust relationship between society and its professions can reduce or eliminate harm or exacerbate problems that people are confronted with on a daily basis. This leads to proposition five:

P5 Stakeholders are more (less) trusting when they view auditors as the guardians (agents of the organization) of reliable and relevant information for their decision-making purposes.

(6) I $\rightarrow \mathbf{P} \rightarrow \mathbf{J} \rightarrow \mathbf{D}$ illustrates the history-based trust and/or dispositional trust that is rooted in the personal experience of recurring exchanges. In addition, personal experiences are augmented by information sources, such as databases, records, archival files, etc.

The historical-based/dispositional trust position takes into account the probability of others likely actions based on past and present information. For instance, contracts are inherently incomplete all the contingencies in a transaction simply cannot be specified. In a long-standing association, exchange is at the center of this course of action. Through this process, organizational dealings are connected to the social setting where psychological issues interlink with economic matters in reaching a decision choice [67]. In the aggregate, the security and constancy of repeated give-and-take interactions permit learning [68] and stimulate trust [69]. This outlook epitomizes the final conceivable distinct manner for people's decision-making based on information processing. 
According to this pathway, a person evaluates the existing evidence (I), frames the issue (P), proceeds to assess the issue $(\mathbf{J})$ to finally arrive at a decision (D) leading to some level of trust or distrust. This leads to the sixth and final proposition:

\section{P6 Auditors' trustworthiness (distrustworthiness) is a function of how independent information can} (cannot) influence their opinions regarding an organizations' performance.

\section{Illustrating Six Trust Pathways: The Case of the Auditors' Going Concern Opinion}

In this Section, we applied the Throughput Model and its six dominant trust/distrust positions in the discussion of auditors' going concern opinions. We illustrate these positions with several examples in Table 2.

From a normative point of view, auditors should maintain an independent (trustworthiness) position in their decision-making process [7]. Investors' reaction to a going concern opinion (i.e., a warning signal) for a client with strong financial distress could be based on trust as a rational choice pathway, $\mathbf{P} \rightarrow \mathbf{D}$. This pathway suggests that evidence (I) is disregarded, and the decision is made without a significant assessment (J). In trusting as a rational choice, investors and other stakeholders are expected to behave in their own interest to make efficient and rational decisions (i.e., encapsulated interest under the social capital framework). That is, investors just trust an auditor's opinion and then will decide whether or not to move their investment to other companies. In this regard, investors perceive that a qualified audit opinion $(\mathbf{P})$ reflects a rational risk to keep their investment in the company. Thus, without looking for further information or making any evaluation of the company's ability to survive, investors would trust auditors' opinions moving their investment to other market opportunities (D).

In this process, investors and stakeholders see auditors as an expert "agent" who contributes to minimize expected losses or maximize expected gains in their transactions [70]. Similarity, potential consumers that trust an auditor's warning signal would decline to buy products of financially distressed companies [7, 71]. Other important trustors of the auditor's report are commercial bankers. To improve financial health, companies may try to get a loan from a bank institution. In this negotiation process, loan officers tend to reject requests for credit when auditors have disclosed concerns in their reports $[72,73]$.

However, the reality is that the auditing market is highly competitive [5] and auditors might face economic incentives to avoid going concern opinions. Several research papers indicate the proportion of going concern opinions for financial distress firms is low [71, 74]. Therefore, despite the fact that the final goal of the auditing profession is to honor and protect public interests, economic factors, such as the fear to be dismissed, or the magnitude of audit and non-audit fees, may affect auditors' independence [75-76]. Audit fees and client size have been some of the indicators used by the empirical research to measure the association between clean audit reports and economic incentives [73, 77]. For example, investors, such as bankers and financial analysts, may rationally distrust a clean audit report when they perceive that the company has been attested for a long time by the same auditing firm (i.e., long term contracts). Another reason to distrust auditors' opinion is the so-called "opinion shopping," that is, when the company management fires the auditor after the receipt of a warning signal about its ability to survive and hires a new one who issues a clean audit report [78-79]. Thus, investors and other users perceiving opinion shopping would distrust clean auditors' opinions regarding firms that are financially distressed. Following this argument, financial statement users will distrust if they perceive that auditors are not protecting their interests when issuing clean reports for financially distressed firms. In this situation, distrust as a rational choice pathway, $\mathbf{P} \rightarrow \mathbf{D}$, may explain investors and other third parties' behavior.

The rule-based trust, $\mathbf{P} \rightarrow \mathbf{J} \rightarrow \mathbf{D}$, highlights auditors' trust relations, whereby they issue their opinion based upon prescribed rules (i.e., moral commitment autonomy under the social capital framework). Rule-based trust describes much of the auditors' explicit and tacit understandings with other individuals. Indeed, it is based on auditors and other parties' common understandings of the 
set of norms concomitant of proper behavior. For instance, auditors draw up a contract (P) based on the rules, that determine if the company abides by the rules $(\mathbf{J})$, and decide $(\mathbf{D})$ on whether to issue an opinion. From the rule-based trust pathway, investors may have confidence in auditors, a self-correcting profession which has reacted after the Enron and other financial scandals. For example, after the Enron-Arthur Andersen scandal, the American Institute of Certified Public Accountants (AICPA) has significantly updated its code of ethics. In addition, recent reforms, including mandatory audit tenure and the banning of non-audit services, have been executed after the passage of the Sarbanes-Oxley Act of 2002 to enhance auditor independence.

However, some authors have argued that compliance with externally imposed rules may not be construed that one is trustworthy [80-81]. This argument is also supported by the so-called "strategy issue cycling" theory recently developed by Moore et al. [82] and Bazerman et al. [83] asserting that current accounting reforms, rather than overcome auditors' ethical dilemmas, seem to hide the reluctance of the auditing profession to make changes in the system. Thus, more regulation, such as the Sarbanes-Oxley Act, may be interpreted as a set of temporary and illusory solutions to an unresolved problem. Here, the rule-based distrust, $\mathbf{P} \rightarrow \mathbf{J} \rightarrow \mathbf{D}$, may help understand why investors distrust auditors' opinions within a robust legal system, which is more "apparent" than real [82-83].

The category-based trust pathway, $\mathbf{I} \rightarrow \mathbf{J} \rightarrow \mathbf{D}$, may explain why investors show a tendency to trust international auditing firms highly. In this regard, big audit firms are seen as a specialist in many sectors (i.e., banking, insurance, high-technology). That is, international audit firms might be categorized as more trustworthiness in comparison to national and regional firms and have strong incentives to protect their reputation in the global market [84]. Also, firms with higher international reputation can hire and retain the best professionals [85]. Following this argument, investors would tend to attribute positive characteristics, such as independence, reputation, industry knowledge, etc. (i.e., psychological disposition under the social capital framework), to international firms. For instance, a clean audit opinion for a company suffering from financial distress issued by a small audit firm would provoke a feeling of distrust. On the other hand, the category-based trust pathway would explain investors' trust in the same unqualified opinion guarantee by a select few large audit firms.

Auditors may be sensitive to third parties as conduits of trust (e.g., newspapers report on litigation), $\mathbf{I} \rightarrow \mathbf{P} \rightarrow \mathbf{D}$, and hence the issuance of an auditor's opinion may alter trust relations with others (e.g., bankers, bondholders, etc.). For instance, a qualified audit report may provoke credit rating agencies to lower their recommendation (e.g., from "investment grade" to "junk") [86-87]. Thus, third parties' information (i.e., the financial press, financial analysts, credit rating agencies) (I) might serve to reinforce investors' trustworthiness (P), and an auditor's opinion would be trusted/distrusted (D). Furthermore, third parties as conduits of the distrust pathway are also useful to illustrate why Arthur Andersen lost its reputation and, consequently, most of its clients after the intense press coverage of the Enron scandal, where that auditing firm never issued a previous warning signal about the company's financial health.

From the role-based trust point of view $\mathbf{P} \rightarrow \mathbf{I} \rightarrow \mathbf{J} \rightarrow \mathbf{D}$, an auditor's decision to avoid a going concern opinion might be seen as a trustworthy behavior if the auditor takes into account the environmental conditions that affect a client's ability to survive. In deciding to issue a qualified audit report, auditors face the so-called "self-fulfilling prophecy effect", that is, a market belief that a going concern opinion will contribute to a client's failure due to its negative impact on creditors, investors, suppliers and customers who would lose their confidence in the company [6-7, 44, 73] [88-89]. For instance, the issuance of a going concern opinion has been found to cause clients' stock price declines [90] and reduce a loan officer's willingness to approve a loan request [72, 73]. Then, the auditor's decision of avoiding a going concern opinion (I) can be trusted (D) whether the investors believe there is still a chance for the company to recover its financial health $(\mathrm{J})$ and perceive that the release of a warning signal will unnecessarily hasten users' confidence in the client $(\mathbf{P})$. 
Table 2. Simultaneous Trust/Distrust Positions on Auditors' Going Concern Opinions.

\begin{tabular}{|c|c|c|c|c|}
\hline \multicolumn{2}{|c|}{ Position } & $\begin{array}{c}\text { Trustworthiness } \\
\text { level }\end{array}$ & Definition & Examples \\
\hline \multirow{2}{*}{\multicolumn{2}{|c|}{ 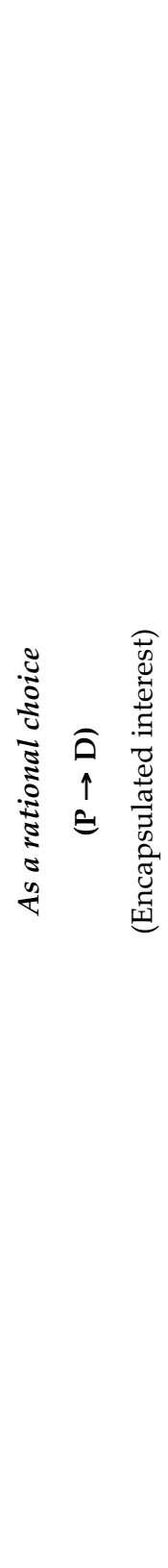 }} & Trust & $\begin{array}{l}\text { Investors and stakeholders } \\
\text { see auditors as expert } \\
\text { "agents" contributing to } \\
\text { minimize expected losses or } \\
\text { maximize expected gains in } \\
\text { their transactions, whereby } \\
\text { the issuance of a warning } \\
\text { signal is interpreted as } \\
\text { protecting investors and } \\
\text { stakeholders' interests }\end{array}$ & $\begin{array}{l}\text { - Loan officers tend to reject requests for } \\
\text { credit when auditors have disclosed } \\
\text { concerns in their reports. } \\
\text { - Stockholders move their investment to } \\
\text { other companies after the issuance of a } \\
\text { warning signal. } \\
\text { - Potential consumers that trust auditors } \\
\text { may decline to buy products of companies } \\
\text { receiving warning signals. } \\
\text { - Suppliers may fear that the client will not } \\
\text { be able to pay once a going concern } \\
\text { opinion has been issued. }\end{array}$ \\
\hline & & Distrust & $\begin{array}{l}\text { Investors and stakeholders } \\
\text { may perceive that auditors } \\
\text { have strong economic } \\
\text { incentives to avoid the } \\
\text { issuance of a warning signal. } \\
\text { Thus, they distrust auditors' } \\
\text { clean opinions on the ability } \\
\text { of their clients to continue in } \\
\text { existence }\end{array}$ & $\begin{array}{l}\text { - The higher the size of the client, the lower } \\
\text { the possibility to receive a going concern } \\
\text { opinion. } \\
\text { - Auditors are less prone to issue a going } \\
\text { concern opinion for new clients and for } \\
\text { those that they have been serving for } \\
\text { several years (e.g., Arthur Andersen was } \\
\text { auditing Enron for about sixteen years, } \\
\text { KPMG was Xerox's auditor for } \\
\text { approximately } 40 \text { years, etc.). } \\
\text { - Given the current highly competitive } \\
\text { auditing market, the recent loss of audit } \\
\text { clients appears to decrease future going } \\
\text { concern opinions. } \\
\text { - Only a few number of financially unhealthy } \\
\text { firms receive a going concern opinion from } \\
\text { their auditors. }\end{array}$ \\
\hline
\end{tabular}




\begin{tabular}{|c|c|c|c|c|}
\hline \multirow[t]{2}{*}{ 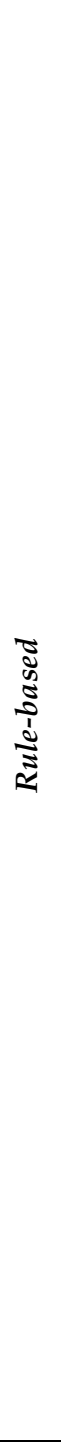 } & \multirow{2}{*}{ 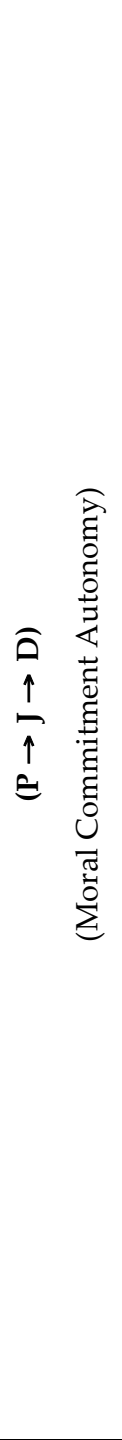 } & Trust & $\begin{array}{l}\text { Investors and other } \\
\text { stakeholders may see the } \\
\text { auditing profession as ethical } \\
\text { exemplary due to a rigorous } \\
\text { normative rule or legal } \\
\text { system function in force. Also, } \\
\text { the auditing profession may } \\
\text { be viewed as a self-correcting } \\
\text { profession which has } \\
\text { positively reacted after the } \\
\text { Enron-Arthur Andersen } \\
\text { episode and other recent } \\
\text { financial scandals }\end{array}$ & $\begin{array}{l}\text { - The AICPA has significantly updated its } \\
\text { code of ethics. } \\
\text { - The SOX may have contributed to mitigate } \\
\text { auditor economic motives as well as by } \\
\text { properly regulating auditor independence. } \\
\text { - The European Commission mandated } \\
\text { mandatory audit firm rotation, banned } \\
\text { most of non-audit services, and imposed a } \\
\text { limitation on permitted non-audit services. }\end{array}$ \\
\hline & & Distrust & $\begin{array}{l}\text { Investors and other } \\
\text { stakeholders perceive that the } \\
\text { weak current legal system } \\
\text { leads them to highly distrust } \\
\text { auditors' opinions (i.e., } \\
\text { strategy issue cycling theory) }\end{array}$ & $\begin{array}{l}\text { - Contrary to the rule-based trust position, the } \\
\text { SOX may be viewed as a set of inefficient } \\
\text { rules and laws. } \\
\text { - The AICPA might update its code of ethics } \\
\text { just to maintain its status quo against } \\
\text { public interest after resounding financial } \\
\text { scandals. } \\
\text { - The PCAOB still nixes mandatory auditor } \\
\text { rotation due to the heavy resistance of } \\
\text { corporate board members and large } \\
\text { companies. }\end{array}$ \\
\hline \multirow[t]{2}{*}{$\begin{array}{c}0 \\
0 \\
0 \\
0 \\
0 \\
0 \\
1 \\
0 \\
0 \\
0 \\
0 \\
0 \\
0\end{array}$} & \multirow{2}{*}{ 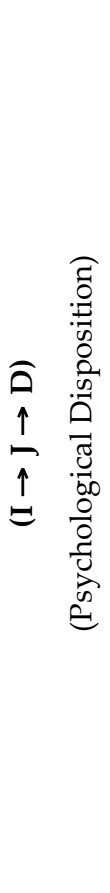 } & Trust & $\begin{array}{lll}\text { Investors and other } & \text { and } \\
\text { stakeholders highly } & \text { trust } \\
\text { auditors' opinions } & \text { from } \\
\text { international accounting firms }\end{array}$ & $\begin{array}{l}\text { - In terms of a superior reputation, } \\
\text { international auditing firms are viewed as } \\
\text { high-status companies that convey more } \\
\text { legitimacy than small audit firms. } \\
\text { - High-status audit firms are considered as } \\
\text { experts in many sectors, such as banking, } \\
\text { insurance, and high technology. } \\
\text { - International auditing firms have a } \\
\text { superior ability to recruit, retain and } \\
\text { motivate the very best professionals. }\end{array}$ \\
\hline & & Distrust & $\begin{array}{l}\text { Investors and other } \\
\text { stakeholders tend to distrust } \\
\text { auditors' opinions issued by } \\
\text { small auditing firms. }\end{array}$ & $\begin{array}{l}\text { - Small audit firms have more economic } \\
\text { incentives to be dependent on their clients. } \\
\text { - Non-international accounting firms do not } \\
\text { possess enough expertise to issue on-time } \\
\text { warning signals regarding their client's risk } \\
\text { of bankruptcy. }\end{array}$ \\
\hline
\end{tabular}




\begin{tabular}{|c|c|c|c|c|}
\hline 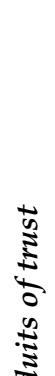 & 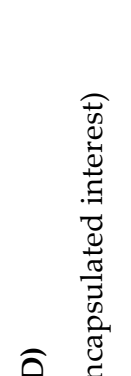 & Trust & $\begin{array}{l}\text { Investors and other } \\
\text { stakeholders highly trust } \\
\text { auditors' opinions when } \\
\text { media reports support their } \\
\text { clients' financial (either } \\
\text { healthy or distressed) status }\end{array}$ & $\begin{array}{l}\text { - Negative news of the client in the press } \\
\text { increases auditors' propensity to issue } \\
\text { going concern opinions. } \\
\text { - Credit rating agencies scores affect } \\
\text { auditors' understanding of their clients' } \\
\text { financial status. }\end{array}$ \\
\hline 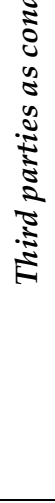 & 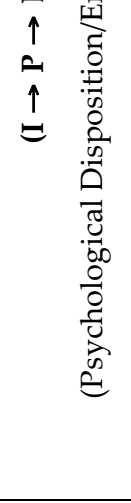 & Distrust & $\begin{array}{l}\text { Investors and stakeholders } \\
\text { highly distrust on auditors } \\
\text { involved in financial scandals } \\
\text { and corruption cases }\end{array}$ & $\begin{array}{l}\text { - The Arthur Andersen dramatic collapse } \\
\text { after the media coverage on the financial } \\
\text { scandal of Enron, which, at the time, was } \\
\text { one of the world's top accounting firms. } \\
\text { - PricewaterhouseCoopers paid } \$ 175 \text { million } \\
\text { in 1998, as a result of a lawsuit due to its } \\
\text { inappropriate way of examining the } \\
\text { financial records of Bank of Credit and } \\
\text { Commerce International (BCCI). }\end{array}$ \\
\hline 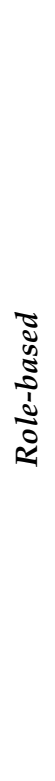 & 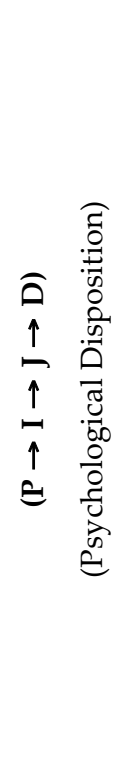 & Trust & $\begin{array}{l}\text { Investors and stakeholders } \\
\text { may perceive auditors' } \\
\text { decision to issue a clean audit } \\
\text { opinion for a financially } \\
\text { distressed client might be } \\
\text { seen as a trustworthy } \\
\text { behavior if the auditor takes } \\
\text { into account the } \\
\text { environmental conditions that } \\
\text { affect client's ability to } \\
\text { survive. }\end{array}$ & $\begin{array}{l}\text { - There is a market belief that suggests that a } \\
\text { going concern opinion directly contributes } \\
\text { to provoke the final bankruptcy of an } \\
\text { already distressed client (i.e., going concern } \\
\text { opinion serving as a self-fulfilling } \\
\text { prophecy). For instance, many commercial } \\
\text { banks reject firms' request for financing } \\
\text { when those firms have received a warning } \\
\text { signal from their auditors. } \\
\text { - Auditors' fear of causing damage to their } \\
\text { clients' shareholders. Several research } \\
\text { reports indicate that the issuance of a going } \\
\text { concern opinion significantly reduces } \\
\text { clients' stock price. }\end{array}$ \\
\hline
\end{tabular}




\begin{tabular}{|c|c|c|c|c|}
\hline & & Distrust & $\begin{array}{l}\text { Investors and stakeholders } \\
\text { may perceive an auditor's } \\
\text { decision to issue a going } \\
\text { concern opinion (clean } \\
\text { opinion) for a financially } \\
\text { distressed client like an } \\
\text { untrustworthy behavior } \\
\text { under a high (low) risk } \\
\text { exposure auditing } \\
\text { environment }\end{array}$ & $\begin{array}{l}\text { - In the light of the recent financial scandals, } \\
\text { auditors fear they will lose their market } \\
\text { reputation when involved in. Thus, } \\
\text { investors may perceive that auditing firms, } \\
\text { rather than improve their compliance with } \\
\text { externally imposed rules (e.g., Sarbanes } \\
\text { Oxley Act), have increased the likelihood to } \\
\text { issue going concern opinions to protect } \\
\text { their market reputation. } \\
\text { - Many auditing firms use their audit report } \\
\text { containing a going concern opinion as a } \\
\text { shield for potential lawsuits. } \\
\text { - In auditing environments with low } \\
\text { litigation risk, such as the cases of Spain, } \\
\text { Belgium, and Hong Kong, auditors may } \\
\text { offer a high reluctance to alert investors. }\end{array}$ \\
\hline : & 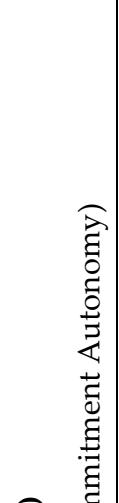 & Trust & $\begin{array}{l}\text { Investors and stakeholders } \\
\text { may trust a clean audit } \\
\text { opinion (warning signal) for a } \\
\text { financially distressed client } \\
\text { might as a trustworthy } \\
\text { behavior if they perceive that } \\
\text { available information } \\
\text { dominates auditors' decision }\end{array}$ & $\begin{array}{l}\text { - Auditors are in the best position to assess } \\
\text { the going concern assumption due to their } \\
\text { expertise and their privileged access to } \\
\text { insider information. } \\
\text { - After examining the financial information } \\
\text { of a distressed client, the auditor must } \\
\text { evaluate both management's plans (i.e., } \\
\text { forecasts, budgets) and abilities to conclude } \\
\text { the firm's risk of bankruptcy. }\end{array}$ \\
\hline 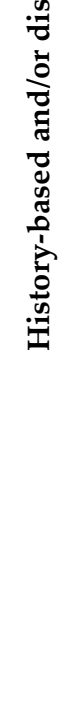 & 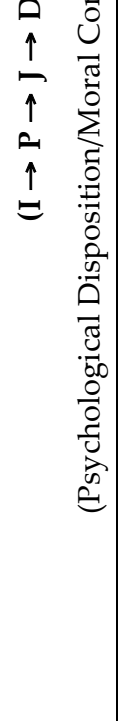 & Distrust & $\begin{array}{l}\text { Investors and stakeholders } \\
\text { may perceive a clean audit } \\
\text { opinion for a financially } \\
\text { distressed client as an } \\
\text { untrustworthy behavior if } \\
\text { they perceive that auditors' } \\
\text { decision may be } \\
\text { unconsciously biased when } \\
\text { processing independent } \\
\text { information (e.g., Bazerman et } \\
\text { al.'s moral seduction theory } \\
\text { [79]) }\end{array}$ & $\begin{array}{l}\text { - Selective perception, escalation of commitment } \\
\text { and discounting of information biases illustrate } \\
\text { auditors' unintended predisposition to } \\
\text { reach their own interest even when they } \\
\text { want to honor public trust. For instance, to } \\
\text { preserve future quasi-rents (audit fees), } \\
\text { auditors may be unintentionally reluctant } \\
\text { to issue going concern opinions. }\end{array}$ \\
\hline
\end{tabular}

However, under the role-based distrust pathway, the issuance of a going concern opinion may lead stakeholders to distrust auditors. In recent years, some accounting auditing firms have issued going-concern opinions for companies that eventually went bankrupt. As a result, most of the financial and non-financial press has repeatedly asked auditors the reasons why they did not issue on time going concern opinions. This situation has provoked a new high risk-litigation environment 
in which investors and other stakeholders now have a higher tendency to sue auditors [91-92]. Following this argument, the chance of being sued by stakeholders would lead auditors to perceive that the potential costs of alerting them can be significantly greater compared to issuing a clean audit opinion.

Finally, the history-based trust and/or dispositional trust pathway, $\mathbf{I} \rightarrow \mathbf{P} \rightarrow \mathbf{J} \rightarrow \mathbf{D}$, represents auditors' trust relations given a sufficient amount of information in an attempt to behave in a normative way. This pathway assumes that evidence influences auditor's perception in an "unbiased" manner leading. For example, the consideration of the feasibility of management's future plans can be critical information to avoid a going concern opinion [18]. Besides, the history-based distrust argument might explain why auditors' psychological disposition may lead investors to distrust auditors' role as vanguards. Moral seduction theory suggests that the unique complexity of the auditor-client relationship precipitates auditors' unintended lack of professional skepticism. Thus, even the most open-minded and diligent of auditors may be unconsciously biased when processing information [6-7, 82-83].

\section{Discussion and Conclusions}

A vast variety of social capital devices, including institutions, norms, and so forth, enable individuals/organizations to cooperate efficiently and effectively. In this paper, we propose the Throughput Model as an efficient mechanism to better understand why auditors may act in a manner that seems not to exploit social capital for positive results. Social capital augmented in a positive manner is 'satisfactory' for civilization bestowing to the ethical sources of standard philosophy, not rendering to the moral aspects of a particular assemblage of people or culture. Beliefs about what is right, just and fair are possible influences on social capital.

The Throughput Model can provide more insight on auditors' and other professionals' deliberations when they are confronted with the task of being the guardian of public trust. That is, the model posits six dominant decision pathways that can influence knowledge transfer from client and auditor informants effective enough to establish their trustworthiness [93]. We believe that understanding the complexity of auditor trustworthiness is paramount to improving social capital and maintaining sustainable financial markets [3-4, 94-95].

Our research has important practical implications for auditors, auditees, and regulators. For instance, consider the long debate about imposing mandatory audit firm rotation to enhance auditor independence and, as a result, audit quality. On the one hand, trust can be enhance if regulators enforce mandatory audit firm rotation as an effective way to increase auditor independence when a long association with audit clients exists (rule-based trust). However, mandatory firm rotation may also create distrust since it is likely to result in a loss of client-specific knowledge (category-based distrust) [96]. Alternatively, regulators may consider to enhance trust by imposing joint audits, i.e., a team of two or more auditors sharing responsibility and providing a single audit report (rule-based trust) [97].

Our study has limitations. First, we rely on a single decision-making model, namely the Throughput model, to illustrate how main financial statements users can trust auditors' going concern opinions. Alternative models with a different conceptualization of trust antecedents, such as personality-based trust or cognition-based trust (i.e., built on first impressions), could be also useful to examine our research question [98]. Second, there are other important decisions made by auditors. For example, consider auditors' opinion on their clients' internal control systems. This remains as an important research question since the vast majority of public companies with clean internal control audit opinions announcing subsequent restatements continues to be very high, around 75 percent in 2015 [99]. Finally, while we have focused our analysis on main financial stakeholders, it is also possible that non-financial stakeholders, such as governments, the media, not-for-profit organizations, regulators, etc., may trust/distrust auditors' opinions in a different manner.

Future research can study whether a particular trust position, supported by a particular decision-making pathway, is more appropriate given a particular situation involving "trust." Also, 
future research can explore which decision-making pathway can typify better relationships between organizations; their auditors and investors' trust positions; and ultimately the improvement of social capital for society at large. Finally, the model's different pathways can allow us to understand better how trust is nurtured and eroded as different parties interact.

Author Contributions: Conceptualization, W.R., A.G. and J.A.G.; methodology, W.R., A.G. and J.A.G.; investigation, W.R., A.G. and J.A.G.; writing-original draft preparation, W.R., A.G. and J.A.G.; writing-review and editing, W.R., A.G. and J.A.G.; supervision, W.R., A.G. and J.A.G.

Funding: This research was supported by Spain's Ministry of Economy and Competitiveness: [Grant Number ECO2015-66240-P].

456 Conflicts of Interest: The authors declare no conflicts of interest.

\section{References}

458 1. Rodgers, W. Knowledge Creation: Going Beyond Published Financial Information; Nova Publication: Hauppauge, NY, USA, 2016.

2. Putnam, R. D. Making democracy work: Civic traditions in modern Italy. Princeton University Press: Princeton, USA, 1993.

3. Szczepankiewicz, E.I. Definitions and Selected Aspects of Measuring and Improving Social Capital in Organisations. IN P. Jeżak (ed.), Social Aspect of Market Economy (pp. 317-335). Częstochowa, AJD, 2011.

4. Coleman, J.S. Social capital in the creation of human capital. Amer. J. Socio. 1988, 94, 95-120.

5. Duska, R.; Duska, B. Accounting Ethics. Blackwell Publishing: Oxford, UK, 2003.

6. Guiral, A.; Rodgers, W.; Ruiz, E.; Gonzalo, J. A. Ethical dilemmas in auditing: Dishonesty or unintentional bias? J. Bus. Ethics 2010, 91, 151-166.

7. Rodgers, W.; Guiral, A.; Gonzalo, J. A. Different pathways that suggest whether auditors' going concern opinions are ethically based. J. Bus. Ethics 2009, 86, 347-361.

8. Lewicki, R. J.; McAllister, D. J.; Bies, R. J. Trust and distrust: New relationships and realities. Acad. Manag. Rev. 1988 23, 438-458.

9. Elfenbein, D. W.; Zenger, T. R. What is a relationship worth? Repeated exchange and the development and deployment of relational capital. Organ. Sci. 2014 25, 222-244.

10. Levine, E.E.; Schweitzer, M.E. Prosocial lies: When deception breeds trust. Organ. Behav. Hum. Dec. Proc. 2015, 126, 88-106.

11. Parkhe, A.; Miller, S. R. The structure of optimal trust: A comment and some extensions. Acad. Manag. Rev. 2000, 25, 10-11.

12. Flores, F.; Solomon, R. Creating trust. Bus. Ethics. Quart. 1998, 8, 205-232.

13. Dellarocas, C. The digitization of word of mouth: Promise and challenges of online feedback mechanisms. Manag. Sci. 2003, 49, 1407-1424.

14. Sabater, J.; Sierra, C. Review on computational trust and reputation models. Artif. Intellig. Rev. 2005, 24, 33-60.

15. Scott, S.V.; Walsham, G. Reconceptualizing and managing reputation risk in the knowledge economy: Toward reputable action. Organ. Sci. 2005, 16, 308-322.

16. Szczepankiewicz, E.I., The role of the audit committee, the internal auditor and the statutory auditor as the bodies supporting effective corporate governance in banks. Finanse, Rynki, Ubezpieczenia, 2011, 38, 885-897.

17. Szczepankiewicz, E.I., The role and tasks of the Internal Audit and Audit Committee as bodies supporting effective Corporate Governance in Insurance Sector Institutions in Poland. Oeconomia Copernicana, 2012, 4, 23-39.

18. Abbott, L.J., Parker S.; Peters, G. The effects of post-bankruptcy financing on going concern reporting. Adv. Account. 2003, 20, 1-20.

19. Rodgers, W. Throughput Modeling: Financial information used by decision makers. JAI Press: Greenwich, CT, 1997.

20. Rodgers, W. E-commerce and biometric issues addressed in a Throughput Model. Nova Publication: Hauppauge, NY, 2010. 
21. Kramer, R. M. Trust and distrust in organizations: Emerging perspectives, enduring questions. Ann. Rev. Psych. 1999, 50, 569-598.

22. Carroll, A. B. The pyramid of corporate social responsibility: Toward the moral management of organizational stakeholders, Bus. Horizons. 1991, 34, 39-48.

23. Doney, P.M., Cannon, J.P.; Mullen, M. R. Understanding the influence of national culture on the development of trust. Acad. Manag. Rev. 1998, 23, 601-620.

24. Kleinman, G.; Palmon, D.A negotiation-oriented model of auditor-client relationships. Group Decis. Negot. 2000, 9, 17-45.

25. Lioukas, C.S.; Reuer, J.J. Isolating trust outcomes from exchange relationships: Social exchange and learning benefits of prior ties in alliances. Acad. Manag. J. 2015, 58(6), 1826-1847.

26. McEvily, B., Zaheer, A.; Kamal, D.F. Mutual and exclusive: Dyadic sources of trust in interorganizational exchange. Organ. Sci. 2017, 28(1), 74-92.

27. Sparrowe, R.T., Liden, R.C., Wayne, S. J.; Kramer, M.L. Social networks and the performance of individuals and groups. Acad. Manag. J. 2001, 44, 316-325.

28. Gambetta, D. Mafia: The price of distrust. In D. Gambetta (Ed.), Trust: Making and breaking cooperative relations (pp.154-175). Oxford: Basil Bernstein, 1998.

29. Ryan, L.V.; Buchholtz, A.K. Trust, risk, and shareholder decision making: An investor perspective on corporate governance. Bus. Ethics. Quart. 2001, 11, 177-193.

30. Axelrod, R. The evolution of cooperation. Basic Books: New York, NY, 1984.

31. Kim, P. H., Ferrin, D. L., Cooper, C.D.; Dirks, K.T. Removing the shadow of suspicion: The effects of apology versus denial for repairing competence-versus integrity-based trust violation. J. Appl. Psych. 2004, $89,104-118$.

32. Luhmann, N. Trust and power. Wiley: New York, NY, 1979.

33. Hardin, R. Trust and Trustworthiness. Russell Sage Foundation: New York, NY, 2002.

34. Whitener, E.M., Brodt, S.E., Korsgaard, M.A.; Werner, J.M. Managers as initiators of trust: An exchange relationship framework for understanding managerial trustworthy behavior. Acad. Manag. Rev. 1998, 23, 513-530.

35. Duska, R. The good auditor-skeptic or wealth accumulator? Ethical lessons learned from the Arthur Andersen debacle. J. Bus. Ethics 2005, 57, 17- 29.

36. Barnes, P. The auditors' going concern decision and types I and II errors: The Coase theorem, transaction costs, bargaining power and attempts to mislead. J. Account. Public Policy 2004, 23, 415-440.

37. Feng, M.; Chan, L. Are Auditors Professionally Skeptical? Evidence from Auditors' Going-Concern Opinions and Management Earnings Forecasts. J. Account. Res. 2014, 52, 1061-1085.

38. Rodgers, W. The effects of accounting information on individuals' perceptual processes. J. Account. Audit. Fin. 1992, 7, 67-95.

39. Rodgers, W. The influences of conflicting information on novices' and loan officers' actions. J. Econ. Psych. 1999, 20, 123-145.

40. Rodgers, W.; Gago, S. A model capturing ethics and executive compensation. J. Bus. Ethics 2001, 48, 189202.

41. Rodgers, W.; Gago, S. Stakeholder influence on corporate strategies over time. J. Bus. Ethics 2004, 52, 349363.

42. Rodgers, W., Söderbom, A. ; Guiral, A. Corporate social responsibility enhanced control systems reducing the likelihood of fraud. J. Bus. Ethics 2015, 185, 871-882.

43. Rodgers, W.; Housel, T.J. The effects of environmental risk information on auditors' decisions about prospective financial statements. Europ. Account. Rev. 2004, 13, 523-540.

44. Guiral, A., Rodgers, W., Ruiz, E.; Gonzalo, J.A. Can expertise mitigate auditors' unintentional biases? J. Internat. Account. Audit. Tax. 2015, 24, 105-117.

45. Foss, K.; Rodgers, W. Enhancing information usefulness by line managers' involvement in cross-unit activities. Organiz. Stud. 2011, 32, 683-703.

46. Culbertson, A.; Rodgers, W. Improving managerial effectiveness in the workplace: The case of sexual harassment of navy women. J. Appl. Soc. Psych. 1997, 27, 1953-1971. 
47. Wicks, A.C., Berman, S.L.; Jones, T.M. The structure of optimal trust: Moral and strategic implications. Acad. Manag. Rev. 1999, 24, 99-116.

48. Morrissey, J.M. International reporting: The way forward. International Federation of Accountants. Retrieved July 24, 2007, from http://www.ifac.org/MediaCenter/?q=node/view/296).

49. Rodgers, W. Thinking Process: Six Pathways to Successful Decision Making. iUniverse, 2006.

50. Currall, S.C.; Epstein, M.J. The Fragility of organizational trust: Lessons from the rise and fall of Enron. Organizat. Dynam. 2003, 32, 193-206.

51. Hosmer, L.T. Trust: The connecting link between organizational theory and philosophical ethics. Acad. Manag. Rev. 1995, 20, 379-403.

52. Hardin, R. Trusting persons, trusting institutions. In R. J. Zechhauser (Ed.), Strategy and choice (pp. 185209). Cambridge, MA: MIT Press, 1991.

53. Brockner, J.; Siegel, P. Understanding the interaction between procedural and distributive justice. In R. M. Kramer; T. R. Tyler (Eds.), Trust in organizations: Frontiers of theory and research (pp. 16-38). Thousand Oaks, CA: Sage, 1996.

54. Hummels, H.; Roosendaal, H.E. Trust in scientific publishing. J. Bus. Ethics 2001, 34, 87-100.

55. Kant, I. Groundwork for the metaphysics of morals. Harper \& Row: New York, NY, 1964.

56. Dore, R. Taking Japan seriously. Stanford University Press: Stanford, CA, 1987.

57. Good, D. Individuals, interpersonal relations, and trust. In D. Gambetta (Ed.), Trust: Making and breaking cooperative relations (pp. 31-48). Oxford: Basil Bernstein, 1988.

58. Mayer, R.C., Davis, J.H.; Schoorman, F.D. An integrative model of organizational trust. Acad. Manag. Rev. 1995, 20, 709-734.

59. Brewer, M.B. In group favoritism: The subtle side of intergroup discrimination. In D. M. Messick; A. Tenbrunsel (Eds.), Codes of conduct: Behavioral research and business ethics (pp. 160-171). New York, NY: Russell Sage Foundation, 1996.

60. Powell, W.W.; Dimaggio, P.J. The new institutionalism in organizational analysis. University of Chicago Press: Chicago, 1991.

61. Labianca, G., Brass, D. J.; Gray, B. Social networks and perceptions of intergroup conflict: The role of negative relationships and third parties. Acad. Manag. J. 1998, 41, 55-67.

62. Blau, P.M. Exchange and power in social life. Wiley: New York, NY, 1964.

63. Beauchamp, T.L.; Bowie, N.E. (Eds.). Ethical theory and business. Upper Saddle River, NJ: Prentice Hall, 1997.

64. Fisher, J., Gunz, S.; McCutheon, J. Private/public interest and the enforcement of a code of professional conduct. J. Bus. Ethics 2001, 34, 191-207.

65. Simon, H.A. Administrative behavior. Macmillan: NY, 1947.

66. Tyler, T.R.; Degoey, P. Trust in organizational authorities: The influence of motive attributions on willingness to accept decisions. In R.M. Kramer; T.R. Tyler (Eds.), Trust in organizations (pp. 331-356). Thousand Oaks, CA: Sage, 1996.

67. Bradach, J.L.; Eccles, R.G. Price, authority, and trust: From ideal types to plural forms. Ann. Rev. Sociol. 1989, 15, 97-118.

68. Hedelin, L.; Allwood, C.M. Managers' strategic decision processes in large organizations. In C. M. Allwood; M. Selart (Eds.), Decision making: Social and creative dimensions (pp. 259-280). Dordrecht, The Netherlands: Kluwer Academic Press, 2001.

69. Powell, W.W. Neither market nor hierarchy: Network forms of organization. In B. M. Staw; L. L. Cummings (Eds.), Research in organizational behavior (pp. 295-336). Greenwich, CT: JAI Press, 1990.

70. Kornish, L.J.; Levine, C.B. Discipline with common agency: The case of audit and non-audit services. Account. Rev. 2004, 79, 173-200.

71. Ruiz-Barbadillo, E., Gómez Aguilar, N., Fuentes-Barbera, C.; García Benau, M.A. Audit quality and the going-concern decision making process: Spanish evidence. Europ. Account. Rev. 2004, 13, 597-620.

72. Guiral-Contreras, A., Gonzalo-Angulo, J.A.; Rodgers, W. Information content and recency effect of the audit report in loan rating decisions. Account. Fin. 2007, 47, 285-304.

73. Guiral, A., Ruiz, E.; Choi, H. Audit report information content and the provision of non-audit services: Evidence from Spanish lending decisions. J. Internat. Account. Audit. Tax. 2014, 23(1), 44-57. 
74. DeFond, M., Raghunandan, K.; Subramanyam, K. Do non-audit service fees impair auditor independence? Evidence from going concern audit opinions. J. Account. Res. 2002, 40, 1247-1274.

75. Reiter, S. A.; Williams, P. F. The philosophy and rhetoric of auditor independence concepts. Bus. Ethics. Quart. 2004, 14, 355-376.

76. DeAngelo, L. Auditor size and audit quality. J. Account. Econ. 1981, 3, 183-199.

77. Vanstraelen, A. Auditor economic incentives and going-concern opinions in a limited litigious continental European business environment: Empirical evidence from Belgium. Account. Bus. Res. 2002, 32, 171-186.

78. Krishnan, J. Auditor switching and conservatism. Account. Rev. 1994, 69, 200-215.

79. Krishnan, J.; Stephens, R.G. Evidence on opinion shopping from audit opinion conservatism. J. Account. Public Policy 1995, 14, 179-201.

80. Nayachi, K.; Watabe, M. Restoring trustworthiness after adverse events: The signaling effects of voluntary "Hostage Posting" on trust. Organ. Behav. Hum. Dec. Proc. 2005, 97, 1-17.

81. Sitkin, S.B.; Roth, N.L. (1993). Explaining the limited effectiveness of legalistic "remedies" for trust/distrust. Organizat. Sci. 1993, 4, 367-392.

82. Moore, D.A., Tetlock, P.E., Tanlu, L.; Bazerman, M.H. Conflicts of interest and the case of auditor independence: Moral seduction and strategic issue cycling. Acad. Manag. Rev. 2006, 31, 10-29.

83. Bazerman, M.H., Moore, D.A., Tetlock, P. E.; Tanlu, L. Reply. Reports of solving the conflicts of interest in auditing are highly exaggerated. Acad. Manag. Rev. 2006, 31, 43-49.

84. O'clock, P.; Devine, K. An investigation of framing and firm size on the auditor's going concern decision. Account. Bus. Res. 1995, 25, 197-207.

85. Greenwood, R., Li, S.X., Prakash, R.; Deephouse, D.L. Reputation, diversification and organizational explanations of performance in professional service firms. Organ. Sci. 2005, 16, 661-675.

86. Joe, J.R. Why press coverage of a client influences the audit opinion. J. Account. Res. 2003, 41, 109-133.

87. Frost, C. A. Loss contingency reports and stock prices: A replication of Banks and Kinney. J. Account. Res. 1991, 29, 157-69.

88. Guiral, A., Ruiz, E.; Rodgers, W. To what extent are auditors' attitudes toward the evidence influenced by the self-fulfilling prophecy? Audit. J. Pract. Theory 2011, 30(1), 173-190.

89. Citron D; Taffler, R. Ethical behaviour in the UK audit profession: The case of the self-fulfilling prophecy under going-concern uncertainties. J. Bus. Ethics 2001, 29, 353-363.

90. Jones, F. The information content of the auditor's going concern evaluation. J. Account. Public Policy 1996, $15,1-27$.

91. Frost, C.A. Uncertainty-modified audit reports and future earnings. Audit. J. Pract. Theory 1994, 13, $22-35$.

92. Kaplan, S.E.; Williams, D.D. Do going concern audit reports protect auditors from litigation? A simultaneous equations approach. Account. Rev. 2013, 88(1), 199-232.

93. Szulanski, G., Cappetta, R.; Jensen, R.J. When and how trustworthiness matters: Knowledge transfer and the moderating effect of causal ambiguity. Organ. Sci. 2004, 15, 600-613.

94. Koehn, D. Transforming our students: Teaching business ethics post-Enron. Bus. Ethics. Quart. 2005, 15(1), 137-151.

95. Rodgers, W. Trust Relationships Viewed from a Throughput Modeling Approach. Nova Publisher: Hauppauge, Nueva York, 2019.

96. Myers, J.N., Myers, L.A., Omer, T.C. Exploring the Term of the Auditor-Client Relationship and the Quality of Earnings: A Case for Mandatory Auditor Rotation? Account. Rev. 2003, 78, 779-799.

97. Zerni, M., Haapamäki, E., Järvinen, T., Niemi, L. Do joint audits improve audit quality? Evidence form voluntary joint audits. Europ. Account. Rev. 2012, 21, 731-765.

98. Gefen, D., Karahanna, E., Straub, D. Trust and TAM in Online Shopping: An Integrated Model. MIS Quart. 2003, 27, 51-90.

99. Audit Analytics. PCAOB Member Updates Internal Control Analysis, 2016. Available at http://www.auditanalytics.com/blog/pcaob-member-updates-internal-control-analysis/ 